\title{
Management of Legal Aid the Challenges in Guarding Law and Justice
}

\author{
Pamungkas Satya Putra \\ Faculty of Law \\ Universitas Singaperbangsa Karawang \\ Karawang, Indonesia \\ pamungkas.satyaputra@fh.unsika.ac.id
}

\author{
Rani Apriani \\ Faculty of Law \\ Universitas Singaperbangsa Karawang \\ Karawang, Indonesia \\ rani.apriani@fh.unsika.ac.id
}

\author{
Bambang Sutedja \\ Faculty of Law \\ Universitas Singaperbangsa Karawang \\ Karawang, Indonesia \\ bambang.sutedja@fh.unsika.ac.id
}

\author{
Wahyu Utamidewi \\ Faculty of Social Science and Political \\ Science \\ Universitas Singaperbangsa \\ Karawang \\ Karawang, Indonesia \\ wahyu.utamidewi@fisip.unsika.ac.id
}

\author{
Adyan Lubis \\ Pusat Bantuan Hukum \\ DPC PERADI Karawang \\ Karawang, Indonesa \\ adyanlubis@gmail.com
}

\begin{abstract}
Legal aid is used as a means of achieving convenience and special treatment as affirmative action (actions are taken directly by the government) to create equality and justice for every underprivileged citizen in the Republic of Indonesia. This effort is inseparable from the Constitutionalism of Legal Aid in Article 28I paragraph (4) and paragraph (5) where the fulfillment of human rights, especially legal aid for the poor, is the responsibility of the state (state responsibility). The purpose of this study is to examine and analyze problems in the implementation of verification and accreditation arrangements for legal aid found in the research location. This study uses a normative juridical approach, a normative juridical approach is used because it is used to research or analyze and explain the theories and principles of legal norms that review the applicable regulations regarding legal aid synchronizing the rules and their application. The benefits in research and community service where Covid-19 has had a negative impact in every sector. Strengthening the character aspect of the law-aware society is very much needed in associations that still carry the New Normal. E-court, which has become a number of concrete steps, is still considered as an effort to digitize not optimal in steps to strengthen the basis of law enforcement and justice.
\end{abstract}

Keywords: Legal Aid, Pandemics, Human Rights, Justice

\section{INTRODUCTION}

In the 1945 Constitution of the Republic of Indonesia in Chapter X Citizens and Residents of Article 27 Paragraph (1) that "All citizens have the same position before the law and government and are obliged to uphold the law and government, without exception". This article confirms the position that every Indonesian citizen has the same basic rights or fundamental rights in the legal process. The logical consequence is that this is the basic basis for the agreement of the founding fathers to implicitly lay the foundation that Legal Aid is a basic obligation in the Indonesian state where the state guarantees the constitutional rights of everyone to get recognition, guarantee, protection, and Just legal certainty and equal treatment before the law as a means of protecting human rights [1]. Including character education in ensuring and implementing human resource development programs for a law-aware community in the Covid-19 and New Normal Pandemic according to zoning determined by the government.

Legal Aid, which is no longer only a basic right but a human right in the Republic of Indonesia, needs serious attention from all circles, both academics, practitioners, and even the public [2]. Legal aid based on the provisions of Law Number 16 Year 2011 concerning Legal Aid is also grounded in Chapter XIV of the National Economy and Social Welfare Article 34 paragraph (2) and paragraph (4). This confirms that humans as creatures of the Almighty God, in essence, their natural existence have the same dignity and dignity and cannot be revoked by anyone, including getting legal assistance for the poor [3]. This effort is inseparable from the provisions of the 1945 Constitution of the Republic of Indonesia Article 28I paragraph (4) and paragraph (5) in which the fulfillment of human rights, especially legal aid for the poor, is the responsibility of the state (state responsibility), especially the central and local governments [4]. The downstream of 
the Legal Aid Research discussed here provides a positive trend for direct application (directly) to the community regarding the implementation of Legal Aid that occurred during the 2019 Corona Virus Disease Pandemic (hereinafter referred to as Covid-19) [5].

The negative impact caused by this pandemic is very pronounced in developing countries, especially in vital sectors, such as the economy and development [6]. The face of the adaptability of legal aid for everyone is a finding that is emphasized in this paper, especially in West Java Province. There are nine policies that have become the government's strategic steps in disaster management, namely:

1. Cut spending plans that are not priority expenditures in the State Revenue and Expenditure Budget (APBN) and Regional Revenue and Expenditure Budget (APBD);

2. Reallocating its budget to accelerate the eradication of the impact of coronavirus, both from a health and economic perspective;

3. Ensuring the availability of staple goods, followed by ensuring the purchasing power of the community, especially the lower class people;

4. The Cash Intensive Program is reproduced and multiplied, provided that it must be followed by compliance with the coronavirus prevention protocol, namely maintaining a safe distance from one another;

5. Provide an additional Rp. 50,000 to cheap basic food cardholders for six months;

6. Accelerate the implementation of pre-employment cards in anticipation of workers who are laid off, workers who lose income, and micro-entrepreneurs;

7. Paying income tax $(\mathrm{PPh})$ Article 21 which has been paid by taxpayers (WP) employees in the manufacturing industry.

8. The Financial Services Authority (OJK) provides credit relaxation under IDR 10 billion for Micro, Small, and Medium Enterprises (MSMEs). The relaxation took the form of lowering interest rates and postponing installments for a year, both from the banking and nonbank financial industries.

9. Low-income people who carry out subsidized housing loans (KPR) will be given a stimulus.

\section{TABLE 1. INDONESIA POLICIES DURING THE COVID-19 PANDEMIC}

\begin{tabular}{|l|l|}
\hline $\begin{array}{l}\text { Regulation instead } \\
\text { of Law Number 1 } \\
\text { Year 2020 }\end{array}$ & $\begin{array}{l}\text { State Financial Policy and Financial Stability } \\
\text { for Handling The 2019 Corona Virus Disease } \\
\text { (Covid-19) Pandemic and/or in Dealing with } \\
\text { Threats That Harm The National Economy } \\
\text { and/or Financial System Stability }\end{array}$ \\
\hline $\begin{array}{l}\text { Government } \\
\text { Regulation Number } \\
21 \text { of 2020 }\end{array}$ & $\begin{array}{l}\text { Large-Scale Social Restrictions in the Context } \\
\text { of Accelerating the Handling of Corona Virus } \\
\text { Disease 2019 (Covid-19) }\end{array}$ \\
\hline $\begin{array}{l}\text { Presidential } \\
\text { Regulation Number } \\
54 \text { of 2020 }\end{array}$ & $\begin{array}{l}\text { Posture Changes and Details of the State } \\
\text { Budget for the 2020 Fiscal Year }\end{array}$ \\
\hline $\begin{array}{l}\text { Presidential Decree } \\
\text { Number 11 of 2020 }\end{array}$ & $\begin{array}{l}\text { Determination of the Corona Virus Disease } \\
2019 \text { (Covid-19) Public Health Emergency }\end{array}$ \\
\hline $\begin{array}{l}\text { Presidential Decree } \\
\text { Number 9 of 2020 }\end{array}$ & $\begin{array}{l}7 \text { of 2020 concerning the Task Force for the } \\
\text { Acceleration of Handling Corona Virus } \\
\text { Disease 2019 (Covid-19) }\end{array}$ \\
\hline Presidential & Refocusing of Activities, Relocation, Budget, \\
\hline
\end{tabular}

Instruction Number $\quad$ and Procurement of Goods and Services in the 4 of $2020 \quad$ Context of Accelerating the Acceleration of Handling Corona Virus Disease 2019 (Covid19)

Based on the description above, the problem statement is as follows: What are the problems in implementing management of the verification and accreditation arrangements for legal aid providers and the challenges in guarding law and justice in the Covid-19 and New Normal Pandemic in Indonesia?

\section{METHODOLOGY}

1. Approach and Type of Research In general

The type of research used in research is qualitative research. In particular, in the realm of law, the research used is a normative juridical legal research approach [7]. The normative juridical approach is used because it is used to research or analyze and explain the theories and principles of legal norms that review the applicable regulations regarding Legal Aid.

2. Research Location

To obtain accurate information or data, which is relevant and relevant to the problem and the completion of this research, the research location was chosen, namely the Republic of Indonesia in general, West Java Province, where specifically for accredited and not accredited legal aid institutions carried out in Karawang Regency, West Java Province (Kanwilkumham Reg. West Java).

3. Types and Sources of Data

The types of data used in this study are: Primary data is data obtained directly from resource persons using the method of observation (observation), interviews (interview) of legal certainty in the implementation of the verification and accreditation regulations for legal aid providers in Law Number 16 of 2011 concerning Legal Aid in the Regional Office of the Ministry of Law and Human Rights, West Java Province (field research is direct research at the research location). b. Secondary data is data obtained from legal materials consisting of:

1). Primary legal materials, by examining legal aid arrangements in the Republic of Indonesia as well as theories that have relevance regarding legal aid, then the contents of the provisions of laws and regulations regarding legal aid which include:

a). The 1945 Constitution of the Republic of Indonesia;

b). Law Number 16 of 2011 concerning Legal Aid;

c). Government Regulation Number 42 of 2013 concerning Requirements and Procedures for Providing Legal Aid and Fund Distribution;

d). Regulation of the Minister of Law and Human Rights Number 10 of 2015 concerning Implementation Regulations of Government Regulation Number 42 of 2013 concerning Terms and Procedures for Providing Legal Aid and Fund Distribution;

e). Regulation of the Minister of Law and Human Rights Number 3 of 2013 concerning Procedures for Verification and Accreditation of Legal Aid Institutions or Community Organizations; 
f). Constitutional Court Decision Case Number 88 /PUU-X/2012, as well as implementing regulations and other technical regulations.

2). Secondary legal materials, by reviewing legal books, articles, and papers from various sources, both printed and electronic media as well as other supporting data relating to the dynamics of verification and accreditation arrangements for legal aid providers and criminal provisions based on Law Number 16 of the year 2011 concerning Legal Aid.

3). Tertiary legal materials, namely data obtained from large dictionaries of the Republic of Indonesia, legal dictionaries and the like, can function to support primary and secondary data.

4. Data Collection Techniques

To obtain the data needed to complete the research carried out [8], the authors use data collection techniques which are divided into:

a. Interview, is a data collection technique by asking direct questions to respondents, Literature Study in this data collection technique is a type of secondary data used to assist the research process, namely by reviewing and analyzing the statutory legislation literature, as well as other data related to the issues discussed in this study.

b. Population and Sample Population and Sample The population in this study includes Character Education to Support Law-Conscious Society in particular and in general for Stakeholders.

c. Data analysis The data analysis method used is qualitative, namely the analysis that combines data in the form of observations, interviews, written materials in the form of books related to this research.

\section{LITERATURE REVIEW}

Talking about Legal Aid in an institution is a legal aid organization that is essentially an organization to achieve a goal continuously [9], as Stephen P. Robbins said that an organization is a consciously coordinated social entity, with a relatively identifiable boundary, which works based on which is relatively continuous to achieve a common goal or a group of goals, and for that, the Field of Consultation and Legal Aid as an organization in terms of maintaining the functions and objectives of the Consultation and Legal Aid Sector as a legal aid organization must have effectiveness in the process so that in the future it can become an organization. better oriented legal aid for the Consultation and Legal Aid Field itself [10].

In achieving the effectiveness of an organization, it is influenced by various factors that vary depending on the nature and field of activity or business of an organization [11]. Each organization has a different frame of reference, this is confirmed again by Hall's opinion that in assessing the effectiveness of an organization many approaches can be used, including the goal attainment approach and the systems approach (The System Approach) [12]. An approach in the sense of how to approach or theory towards achieving a goal. The effectiveness perspective emphasizes the central role of achieving the goals of an organization [13]. Many sets of criteria are used to evaluate organizational effectiveness as stated above, but here will be written only four factors that influence effectiveness, namely organizational characteristics, environmental characteristics, worker characteristics, and management policies and practices [14].

The influence of these 4 factors on organizational effectiveness is as follows [15]:

1. Organizational characteristics, consisting of organizational structure and technology. The structure is a relationship that is relatively fixed in nature as found in organizations.

2. Environmental characteristics include two aspects. The first is the external environment, namely all forces that arise outside the boundaries of the organization and influence decisions and actions within the organization [16]. The second is the internal environment. This environment is generally known as organizational climate, covering various attributes of the work environment.

3. Characteristics of workers, attention should be paid to the role of individual differences between workers about effectiveness [17]. Different workers have different views, goals, needs, and abilities.

4. Management policies and practices, here we will consider how variations in leadership styles, policies, and practices can pay attention to or hinder the achievement of goals [18].

Based on the four characteristic factors that affect organizational effectiveness stated by Steers, it can be explained briefly that [19]:

1. The structure built and the technology used in the organization will greatly influence the process and the achievement of goals.

2. Organization as an open organization, its survival will greatly depend on the surrounding environment, both inside and outside the organization [20].

3. That humans as an important element of the organization have different abilities, motivational views, and cultures [21].

4. Management policies and practices established by the leadership in regulating and controlling the organization are very influential for the organization and the achievement of goals [22].

Therefore, the characteristics of an organization to be effective in achieving its objectives must fulfill the above matters, and the Consultation and Legal Aid Field as a Legal Aid Organization in achieving effectiveness as an organization engaged in the legal field cannot be separated from the above effectiveness theory [23]. The operation of the Consultation and Legal Aid Sector as a Legal Aid Organization in providing legal assistance will of course face various obstacles [24]. This is by Soerjono Soekanto opinion that various factors influence law enforcement, namely [25]:

1. The legal factors themselves, the laws discussed will be limited to the laws only [26].

2. Law enforcement factors, namely the parties who form or implement laws [27];

3. Factors of means or facilities that support law enforcement [28];

4. Community factors, namely the environment in which the law applies or is applied [29];

5. Cultural factors, namely as a result of work, creativity, and taste based on a human initiative in social life [30]. 
Specific concepts which are a collection in a related sense, with terms to be researched and/or described in scientific work [31], so that there is no misunderstanding on the subject matter, then below the authors provide some concepts that can be used as a guide in understanding this paper [32], namely:

1. Effectiveness: Effectiveness is a measure that provides an idea of how far the target can be achieved;

2. Consultation and Legal Aid Sector: Consultation and Legal Aid Sector is a legal aid organization or organization that provides legal assistance services or services to legal aid recipients;

3. Legal Aid Providers: Legal Aid Providers are legal aid institutions or community organizations that provide legal aid services based on Law Number 16 of 2011 concerning Legal Aid;

4. Legal Aid. Legal aid can be interpreted as an effort to help disadvantaged groups in the legal field;

5. Crime. Actions that are prohibited by a prohibition law are accompanied by threats (sanctions) in the form of certain crimes, for those who violate the prohibition.

Understanding how legal certainty must be used as a reference, in this case, is used by Gustav Radbruch's opinion, where legal certainty is "Sicherheit des Rechts Selbst" (legal certainty about the law itself) [33]. There are 4 (four) things related to the meaning of legal certainty, including [34]. Whereas the law is positive, meaning that law is legislation (gesetzliches Recht). Whereas this law is based on facts (Tatsachen), not a formulation of an assessment that will be carried out by the judge, such as "goodwill", "politeness". That the facts must be formulated clearly to avoid confusion in meaning, as well as being easy to implement. The positive law should not be changed frequently [35].

\section{ANALYSIS AND DISCUSSION}

In-Law Number 16 of 2011 concerning Legal Aid, although it is not stated in the preamble Considering the law, it is implied in the Elucidation of Law Number 16 of 2011 concerning Legal Aid which states that: "Although legal aid is not explicitly stated as the responsibility of the state, the provisions of Article 1 paragraph (3) of the 1945 Constitution of the Republic of Indonesia affirms that" the State of Indonesia is a constitutional state ". In a rule of law, the state recognizes and protects human rights for every individual, including the right to legal aid. The provision of legal aid to citizens in an effort to fulfill and at the same time implement a rule of law that recognizes and protects and guarantees the human rights of citizens regarding the need for access to justice and equality before the law [36]. The guarantee of this constitutional right has not received adequate attention, so the formation of this Law on Legal Aid is the basis for the state to guarantee citizens, especially for people or groups of poor people, to get access to justice and equality before the law. Therefore, state responsibility must be implemented through the formation of this Legal Aid Law. So far, the provision of Legal Aid has not touched many people or groups of poor people, so that they have difficulty accessing justice because they are hampered by their inability to realize their constitutional rights. The regulation regarding the provision of legal aid in this law is a guarantee of the constitutional rights of people or groups of poor people.
Law is used as the basis for holding in the administration of a country. In the legal system in the Republic of Indonesia adopting The legal order is a system of norms, it can be seen that the legal system in the Republic of Indonesia is a hierarchy and is based on the basic norms or the highest rules, namely the 1945 Constitution of the Republic of Indonesia. General norms (inferior) must have validity and efficacy and be effective with basic norms in their application in society [37]. Based on these provisions, in real terms the state, in this case, the government, is obliged to provide guarantees for the poor regarding legal aid with sustainable implementation. Legal aid referred to based on Law Number 16 the Year 2011 concerning Legal Aid in Chapter I General Provisions Article 1 point 2 confirms that legal aid recipients are people or groups of poor people. Certainly, to maintain imbalance in the judicial process, especially for underprivileged citizens, the government based on the Constitution implements guarantees to people or groups of poor people in getting justice and equality before the law as a form of implementing the rule of law concept. It has been explained previously that legal aid is an effort made by the state, in this case, the government, to guarantee the rights of every citizen to access justice and equality before the law [38]. The provision of legal aid other than based on the Legal Aid Provision Standards and the Advocate Code of Ethics [39].

There is a dynamic, in which only two (2) institutions can provide Legal Aid, one is a Legal Aid Institution and the second is a Community Organization. Then what about other than advocates, which is regulated in Article 9 letter a of Law Number 16 of 2011 concerning Legal Aid, namely Legal Aid Providers recruit lawyers, paralegals, lecturers, and law faculty students as executors of providing legal assistance that is not required or given clear guidelines on the Code of Ethics for the Implementation of Legal Aid. There are several dynamics in the application of Law Number 16 of 2011 concerning Legal Aid, namely the first regarding the legal position of Legal Aid Providers as regulated in this law which is contained in Chapter I General Provisions Article 1 number 1 and number 3 Juncto Chapter IV Provider Legal Aid Article 8 paragraph (1) and paragraph (2). In the legal aid arrangement in the Republic of Indonesia, it has been rigidly regulated under verification and accreditation which determines the standard of eligibility to be said to be a Legal Aid Provider in the Republic of Indonesia. The process is based on Article 7 paragraph (1) of Law Number 16 of 2011 concerning Legal Aid. As explained in the background, Government Regulation Number 42 of 2013 concerning Requirements and Procedures for Providing Legal Aid and Distribution of Legal Aid Funds confirms in Article 1 number 10 and number 11 confirm that: 10 . Verification is an examination of the accuracy of reports, statements, and documents submitted by a Legal Aid Provider. 11. Accreditation is the recognition of a Legal Aid Provider given by the Verification and Accreditation Committee after it is assessed that the Legal Aid Provider is eligible to provide Legal Aid. 


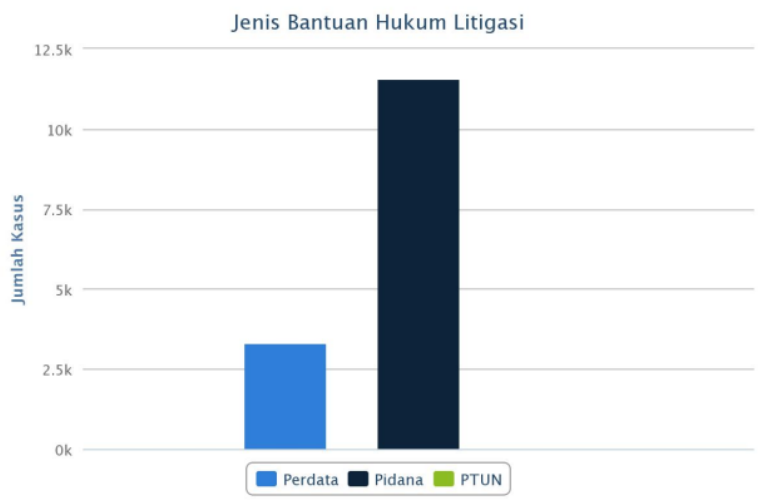

Fig. 1. Types of Legal Aid

The data above is a type of litigation legal aid carried out at the West Java Regional Office of Law and Human Rights in 2018, where there are Civil Cases: 3,334, Criminal Cases: 11,574, and State Administrative Cases: 0. It can be understood from the research findings that, the budget conditions for the Allocation of Legal Aid in 2019 Rp. $5,114,120,000$ and in 2020 Rp. 5,625,320,000 or an increase of $10 \%$ from the previous year. Although the data is not connected to the real needs in the field, West Java Province is one of the most populous provinces with a population of 49.94 million people.

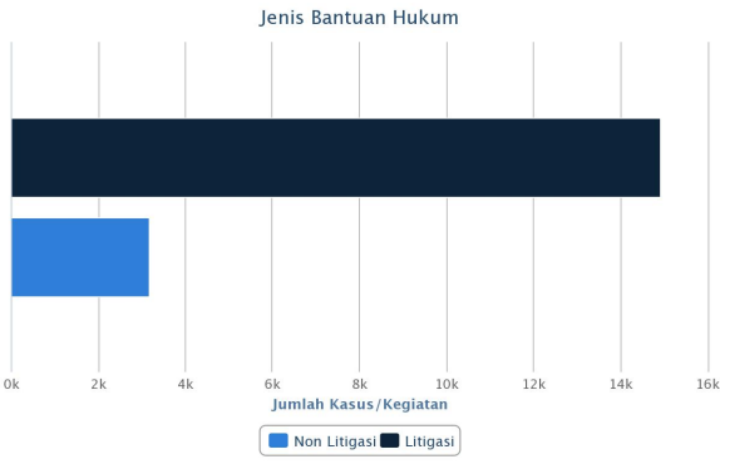

Litigation: 14,924

Non-Litigation: 3,162

Fig. 2. Handling of Legal Aid in West Java

It has been explained in the background that there are things that can be studied in the criminal provisions of Law Number 162011 concerning Legal Aid, Chapter IX of Article 21 of the Criminal Provisions states "Legal Aid Providers who are proven to have received or requested payment from Legal Aid Recipients and/or other parties related to the case being handled as referred to in Article 20, shall be punished with imprisonment of up to 1 (one) year or a maximum fine of Rp. 50,000,000.00 (Fifty Million Rupiah) "is in the form of alternative punishment because the use of legal language, namely the word" or "which implies that the criminal provisions can be imposed on the Legal Aid Provider with imprisonment or fines as an alternative character is the dynamic of the regulation in the provisions. special crimes in the Republic of Indonesia. Another thing that still cannot be seen in Article 21 and needs to be examined is whether each Legal Aid Provider, either alone or jointly, commits a criminal offense is indicated (keeping in mind the presumption of innocence) including the form of crime or violation. Because in the context of the criminal system, this is no longer aimed at the deterrent effect and the effect of suffering on the perpetrators, but the mechanism of preventive or preventive action carried out by the state by regulating and holding the perpetrators to be convicted. The basis and purpose of punishment begin with the idea of retaliation theory which makes the stigma of crime or retaliation the basis for punishment [40]. Then came the criticism of the weakness of the idea of retaliation theory which gave rise to the justification of the concept of punishment, namely the theory of objectives, which asserts that punishment is imposed to prevent crime. The same thing with the retaliation theory in the criminal theory of continued criticism becomes the basic assumption of the formation and renewal of the concept of further punishment, namely the combined theory of retaliation and purpose as a form that can vary in the context of the punishment, although the criminal system can be based on the criminal act itself.

\section{CONCLUSIONS}

The problems that exist are related to re-accreditation and the verification process as regulated in Law Number 16 of 2011 concerning Legal Aid in conjunction with Government Regulation Number 42 of 2013 concerning Requirements and Procedures for Providing Legal Aid and Distribution of Legal Aid Funds, Juncto. Regulation of the Minister of Law and Human Rights of the Republic of Indonesia Number 3 of 2013 concerning Procedures for Verification and Accreditation of Legal Aid Institutions and Civil Society Organizations mentioned above, which sometimes feel too difficult for Legal Aid Organizations to comply with, to be able to carry out the verification and accreditation stages. So that this will have an impact on legal certainty for the provision of legal aid for Legal Aid Organizations that are still carrying out the process of re-accreditation and verification of their organizations. Another problem is that the time for verification and accreditation itself is too long.

\section{ACKNOWLEDGMENT}

The research team would like to thank Universitas Singaperbangsa Karawang, Indonesia through the LPPM for the 2020 community service grants, and also to Partners (PBH DPC PERADI Karawang, Pusat Kajian dan Bantuan Hukum LPPM, UMKM, West Java Regional Office of Kawilkumham and others), as well as the Faculty of Law which is very supportive of this research activity. Including discussants and committees in the $3^{\text {rd }}$ ICOBAME event

\section{REFERENCES}

[1] A Gray; N Rickman; P Fenn. Professional autonomy and the cost of legal aid. Oxford Economic Papers. July 1999;51(3):545-558, https://doi.org/10.1093/oep/51.3. 545

[2] Ali. Achmad., Menguak Teori Hukum (Legal Theory) \& Teori Peradilan (Judicialprudence) Termasuk Undang-Undang (Legisprudence) Volume I Pemahaman Awal. Jakarta: Kencana Prenada Media Group. 2010.

[3] Betsyeba, Gabriel. "Pelaksanaan Bantuan Hukum Cuma-Cuma Yang Diberikan Oleh Advokat Kepada Masyarakat Yang Kurang Mampu". Artikel Ilmiah, Fakultas Hukum UAJY: Yogyakarta. 2013.

[4] Biroli, Alfan.. "Problematika Penegakan Hukum Di Indonesia (Kajian Dengan Perspektif Sosiologi Hukum)". Jurnal Dimensi. Universitas Turnojoyo. Madura. 2015;8(2).

[5] Bradley D. Hays. Nullification and the Political, Legal, and QuasiLegal Constitutions. Publius: The Journal of Federalism. Spring 2013;43(2):205-226, https://doi.org /10.1093/publius/pjs013 
[6] David J. Bodenhamer, Women and Justice for the Poor: A History of Legal Aid, 1863-1945. By Felice Batlan, Journal of Social History. Winter 2016;50(2):443-444. https://doi.org/10.1093/jsh/shv130.

[7] Dragos, D; Neamtu, B. (2017). Freedom of Information in the EU in the midst of Legal Rules, Jurisprudence and Ombudsprudence: The European Ombudsman as Developer of Norms of Good Administration. European Constitutional Law Review. 2017;13(4):641-672. doi:10.1017/S157401961700030X.

[8] Ervasti, K. Problem-Solving Justice in Criminal and Civil Justice in Finland. Utrecht Law Review. 2019;14(3):19-30. DOI: http://doi.org/10.18352/ulr.469

[9] Expert-Foulquier, C. Is French Administrative Justice a ProblemSolving Justice?. Utrecht Law Review. 2019.14(3):40-51. DOI: http://doi.org/10.18352/ulr.470

[10] Fauzi, Suyogi Imam; Inge Puspita Ningtyas. Optimalisas Pemberian Bantuan Hukum Demi Terwujudnya Access to Law and Justice Bagi Rakyat Miskin. Jurnal Konstitusi. 2018 Maret;15(1)

[11] Fowlie, J., \& Wood, M. The emotional impact of leaders' behaviours Journal of European Industrial Training. 2009;(33)6:559-572. https://doi.org/10.1108/03090590910974428.

[12] Griet Vermeesch. The Legal Agency of Single Mothers: Lawsuits over Illegitimate Children and the Uses of Legal Aid to the Poor in the Dutch Town of Leiden (1750-1810). Journal of Social History. Fall 2016;50(1):51-73. https://doi.org/10.1093/jsh/shv096.

[13] Katia Bianchini. Legal Aid for Asylum Seekers: Progress and Challenges in Italy. Journal of Refugee Studies. June 2011;24(2):390 410. https://doi.org/10.10 93/jrs/fer003

[14] Lupo, N., \& Piccirilli, G. The Relocation of the Legality Principle by the European Courts' Case Law: An Italian Perspective. European Constitutional Law Review. 2015;11(1):55-77. doi:10.1017/S15740196150 0005X

[15] Mertokusumo, S. Meningkatkan Kesadaran Hukum. 2008. Available From. http://sudiknoartikel.co.id/ 2008/03/meningkatkan-kesadaranhukum-masyarakat.h tml.

[16] Mengenal Hukum Suatu Pengantar, Yogyakarta: Liberty.

17] Moeljatno. Asas-asas Hukum Pidana. Jakarta: Rineka Cipta. 1993.

[18] Nasution, Adnan Buyung. Bantuan Hukum di Indonesia, Jakarta: LP3ES. 1988.

[19] PEKKA dan AusAID. "Akses terhadap Keadilan: Pemberdayaan Perempuan Kepala Keluarga di Indonesia”. Supra, Kerangka Kerja untuk Penguatan Akses Hukum dan Keadilan di Indonesia, Justice for the Poor Project The World Back: Jakarta. 2010.

[20] PERADI, Indonesia. Profile PERADI. 2018. Available From http://www.peradi.or.id/index.php/profil/detail

[21] Raharjo, Agus. "Akses Keadilan Bagi Rakyat Miskin (Dilema Pemberian Bantuan Hukum Oleh Advokat)". Jurnal Mimbar Hukum. Volume 27. Nomor 3. Edisi Oktober. Fakultas Hukum UGM. Yogyakarta. 2015.

[22] Richard M. Steers. Efektivitas Organisasi, Terjemahan: Magdalena Jamin, Jakarta: Erlangga. 1985.

[23] Riley, S. Human Dignity and the Rule of Law. Utrecht Law Revie., 2015;11(2):91-105. DOI: http://doi.org/ 10.18352/ulr.320.

[24] Rodriquez, S. The Interaction between Private and Public Actors Traditional Principles versus New Trends A Comparative Analysis. Utrecht Law Review. 2018;14(1):157-173. DOI: http://doi.org/10.18352/ulr. 447

[25] Romualdi, G. Problem-Solving Justice and Alternative Dispute Resolution in the Italian Legal Context. Utrecht Law Review. 2019;14(3):52-63. DOI: http://doi.org/ 10.18352/ulr.468.

[26] Salamor, Yonna Beatrix; Anna Maria Salamor. Membangun Kesadaran Hukum dan Pemenuhan Hak-Hak Perempuan di Negeri Seilale, Communnity Development Journal. (1)2. 70-73. Juni 2020.

[27] Sarwono, B. Kesadaran Hukum Perlu dibangun dari Keluarga. Banjarnegara: Suara Merdeka. 2017.

[28] Sedarmayanti. Sumber Daya Manusia dan Produktivitas Kerja Bandung: CV. Mandar Maju. 2009.

[29] Sidharta, B.A. Ilmu Hukum Indonesia, Upaya Pengembangan Ilmu Hukum Sistematik yang Responsif terhadap Perubahan Masyarakat. Yogyakarta: Genta Publishing. 2013.
[30] Soekanto, Soerjono; Sri Mamudji. Penelitian Hukum Normatif: Suatu Tinjauan Singkat. Jakarta: Rajawali Pers. 2012.

[31] Soekanto, S. Faktor-faktor yang Mempengaruhi Penegakan Hukum. Jakarta: Rajawali. 2012.

[32] Kesadaran Hukum dan Kepatuhan Hukum. Jakarta: Rajawali Pers. 1982

[33] Kesadaran Hukum dan Kepatutan Hukum, Jurnal Hukum dan Pembangunan, 7 (6): 462-470. 1977.

[34] Tambunan, Irma. "Bantuan Hukum Gratis Bagi Kaum Miskin," Kompas, 16 Januari. 2017.

[35] Taufik, Lalu Muhammad. "Implementasi Bantuan Hukum Bagi Masyarakat Miskin (Studi Kasus di Pengadilan Agama Mataram)". Jurnal IUS Kajian Hukum dan Keadilan. Volume 5. Nomor 3. Fakultas Hukum. Universitas Mataram. 2017.

[36] Undang-undang Nomor 16 Tahun 2011, tentang Bantuan Hukum, Kemenkumham RI, Jakarta, 2011.

[37] United Nations Development Programme, UNDP. "Strengthening Judicial Intregity through Enhamced Access to Justice (Analysis of the national studies on the capacities of the judicial institutions to address the needs/demands of persons with disabilities, minorities and women)". Thailand. 2013.

[38] United Nations Development Programme, UNDP. "Access to Justice Practice Note". Thailand.United Nations Development Programme, UNDP. (2005). "Programming for Justice: Access for All: A Practitioner's Guide to a Human Rights-Based Approach to Access to Justice". Thailand. 2004

[39] Van Elsuwege, P; Gremmelprez, F. Protecting the Rule of Law in the EU Legal Order: A Constitutional Role for the Court of Justice. European Constitutional Law Review. 2020;16(1):8-32. doi:10.1017/S157401962000 0085.

[40] Yonna Beatrix Salamor. "Pemberian Bantuan Hukum Kepada Masyarakat Miskin di Kota Ambon". Volume 2. Nomor 1. Universitas Tarumanegara. Jakarta. 2018. 